\title{
Aboveground biomass in Prosopis pallida (Humb. and Bonpl. ex Willd.) H. B. K. ecosystems using Landsat 7 ETM+ images
}

\author{
Biomasa aérea en ecosistemas de Prosopis pallida (Humb. and Bonpl. ex Willd.) H. B. K. \\ usando imágenes Landsat 7 ETM+
}

EVA PADRÓN \& RAFAEL M. NAVARRO-CERRILLO*

\begin{abstract}
Departamento de Ingeniería Forestal-Universidad de Córdoba, Apartado de Correos 3048, 14080 Córdoba, España *e-mail para correspondencia: ir1nacer@uco.es
\end{abstract}

\begin{abstract}
The significance of field work in remote sensing studies when applied to large areas has often been underestimated. The combination of specific forest inventories for the estimation of aboveground biomass in large dry tropical forest areas with remote sensor data has scarcely been explored to date. In this work, a systematic, stratified forest inventory involving $100 \times 100 \mathrm{~m}$ square plots in an area of Peruvian Prosopis pallida dry forest, roughly one million hectares in size in the Piura province (Peru) has been compiled. The inventory encompassed the principal silvicultural variables defining the ecosystem studied, which were used in allometric equations for the different species, genera and plant associations in the area in order to estimate the amount of aboveground biomass present in each plot. Field data were related to a Landsat 7 ETM+ image by using six different vegetation indices derived from an image mosaic for the area. Two regression equations (relating the amount of aboveground phytomass to the different vegetation indices) provided reasonably acceptable phytomass predictions for the type of ecosystem concerned $\left(\mathrm{R}^{2}\right.$ between 0.72 and 0.52$)$.
\end{abstract}

Key words: Prosopis pallida, Landsat 7 ETM+, vegetation indices, biomass estimation.

\section{RESUMEN}

La importancia del trabajo de campo en estudios de teledetección radica en la necesidad de proveer una validación a los valores de reflectividad incluidos en los datos de los sensores remotos. La diversidad ecológica del medio forestal y la evaluación de grandes superficies de difícil acceso hacen de la combinación del inventario forestal y de la teledetección una herramienta compleja y útil en el análisis del medio terrestre. El presente trabajo muestra la aplicación de un inventario sistemático estratificado sobre un millón de hectáreas de bosque tropical seco de Prosopis pallida en el Departamento de Piura (Perú) en la validación de diferentes tipos de clasificación realizadas sobre dicho ecosistema mediante el uso de imágenes Landsat $\mathrm{ETM}+$. El inventario recoge las principales variables del ecosistema y de los individuos, tomadas en parcelas de 1 hectárea, que posteriormente fueron relacionadas con los valores de reflectividad de las imágenes mediante el uso de índices de vegetación. Se hallaron ecuaciones de regresión entre valores de fracción de suelo cubierto y cinco índices de vegetación, obteniéndose resultados con $\mathrm{R}^{2}$ de hasta $72 \%$. Los niveles de significación hallados mediante el uso de los índices NDVI y EVI permiten una estimación razonable del estado del bosque seco de Prosopis pallida del Departamento de Piura de una forma económica, fácil de repetir en el tiempo y aplicable a zonas que difícilmente pueden ser evaluadas mediante inventarios convencionales.

Palabras clave: Prosopis pallida, Landsat 7 ETM+, índices de vegetación, estimación de biomasa.

\section{INTRODUCTION}

Phytomass is a key structure variable for research into ecosystem dynamics and it is defined as the net amount of energy fixed by plants (Terradas 2001). The significance of aboveground phytomass (the amount of aboveground dry plant matter per trunk and branch surface area) (Terradas 2001), and the interest in its determination in specific ecosystems, have fostered the use of new technologies, such as remote sensing, for its calculation (Häme et al. 1997, Kueh \& Lim 1999). Data acquired by remote sensors 
(specifically, reflectance data) allow various biophysical properties of forests including phytomass to be estimated. Reflectance, which is taken to be the proportion of incident energy reflected by a surface (Chuvieco 1995), enables the identification of the different states of a forest ecosystem from cut forest to mature canopy (Boyd et al. 1996).

Empirical models relating ground biophysical measurements to remotely acquired data are useful tools for studying forest ecosystems. The variables usually examined in this context are phytomass (Häme et al. 1997, Steninger 2000), leaf area index (LAI) (Reich et al. 1999) and ground cover (Collin et al. 2000, Cohen et al. 2003). Among other purposes, remote sensing is useful for detecting forest changes and acquiring data for their different development stages (Boyd et al. 1996, Shu 2003). This is made easier by the fact that the regeneration stages of forests are related to their biophysical properties (Cohen et al. 2003). These properties, which include tree height, diameter at breast height $(\mathrm{DBH})$, leaf area index (LAI) and tree density, influence the amount of radiation that is reflected or emitted by the canopy.

A number of remote sensing studies have been conducted with a view to relating ground biophysical parameters in general (Boyd et al. 1996, Cohen et al. 2003), and biomass in particular (Häme et al. 1997, Steninger 2000), to the digital values contained in each Landsat image band. While remote sensing and biomass studies in tropical areas have long been focussed on wet forests (Steninger 2000, Pua \& Saito 2003) on the grounds of their worldwide significance, there have also been some studies on biomass in dry tropical forests (Guerra et al. 1998, Arroyo-Mora et al. 2003).

Stratifying biomass areas in dry forest ecosystems can be very useful for managing forest resources and estimating their carbon fixation capacity. The amount of matter contained in an ecosystem can also be used to assess its potential uses and whether wood extraction is viable or to what extent it should be restricted in order to reduce the risk of degradation, deforestation and desertization (Roper \& Roberts 1999).

No specific studies appear to have been conducted for estimating the amount of aboveground biomass present in Peruvian
Prosopis pallida ecosystems. The aim of this work was to construct an empirical model to relate aboveground phytomass in the Prosopis pallida dry forest ecosystem of the Piura Province (Perú) to reflectance values derived from images obtained by the Landsat ETM+ sensor in the year 2000 .

\section{MATERIAL AND METHODS}

\section{Study area}

The Prosopis pallida dry forest studied spanned an area of one million hectares located between $04^{\circ} 05^{\prime}, 06^{\circ} 22^{\prime} \mathrm{S}$ and $79^{\circ} 00^{\prime}, 81^{\circ} 07^{\prime} \mathrm{W}$ in the Piura Province (north-western Peru, South America). Its boundaries were Tumbes (Perú) and the Republic of Ecuador to the north, Lambayeque to the south, Cajamarca to the east and the Pacific Ocean to the west (Fig. 1).

The study area consists mainly of forests, the principal species is Prosopis pallida H.B.K. (algarrobo), accompanied by Loxopterygium huasango Spruce ex Engl. (hualtaco), Bursera graveolens (Kunth) Triana and Planch. (palo santo), Capparis angulata R. \& P. (sapote) in the tree stratum; and by Cordia lutea Lam. (overo), Capparis ovalifolia R. \& P. (bichayo), Capparis cordata R. \& P. (satuyo), Ipomoea carnea Cav. (borrachera), Acacia huarango Macbr. (faique), Pithecellobium excelsum (Kunth) Martius (chaquiro), Bougainvillea spp. (papelillo), Grabowskia boerhaaviaefolia (L.f.) Schlecht. (palo negro) and Encelia canescens Lam. (charamusco) in the bush stratum. The tree stratum comprised individuals with a DAB (diameter at the base) $\geq 10 \mathrm{~cm}$ and the rest of them were considered the regenerate stratum.

The forests in the study area are of the open type, with a tree cover of less than $100 \%$ and they spanned approximately 1 million ha. They lie on semi-desertic plains that may have been formed by aeolian or alluvial deposition of the soil substrate (INRENA 1998).

\section{Sampling design and data collection}

A forest systematic inventory was developed within the study zone using a GPS to locate the central point of each plot. The variables used were as follows: tree, Prosopis, bush, regenerate ground cover (by measuring 


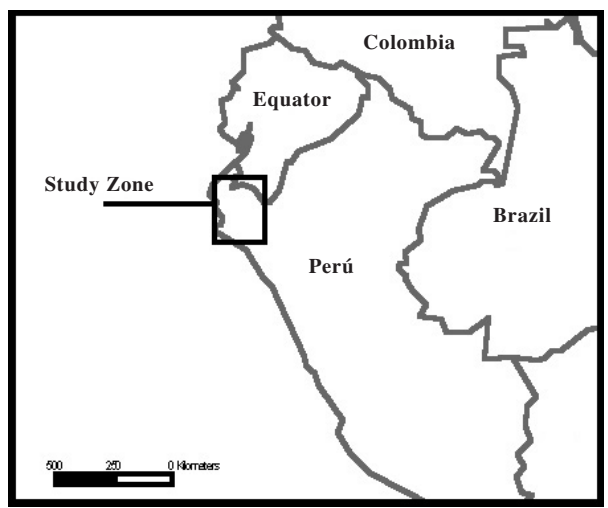

\section{PIURA DEPARTMENT}

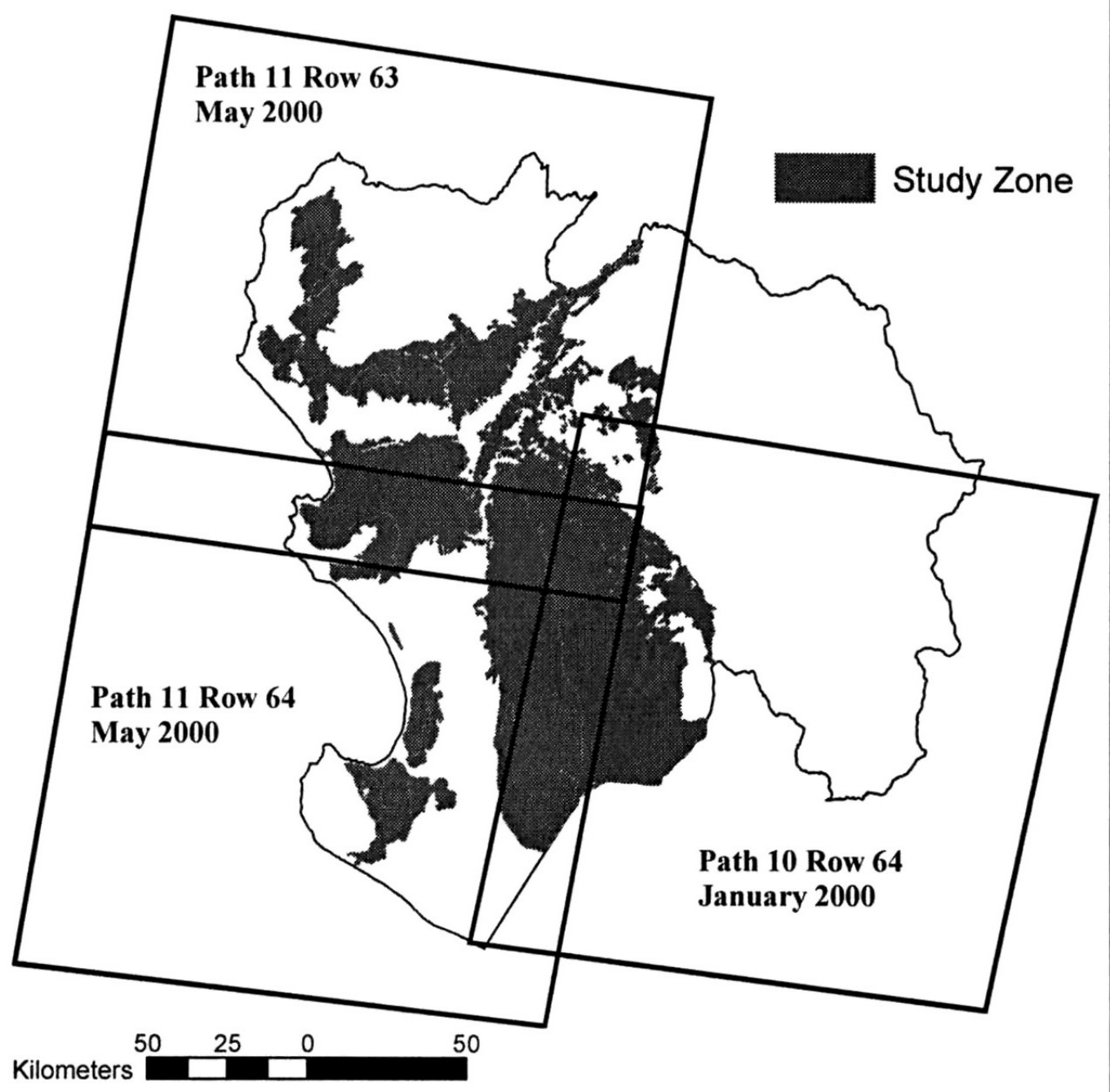

Fig. 1: Location of the images and the study area in the Piura Province.

Ubicación de las imágenes y área de estudio en la Provincia de Piura. 
perpendicular crown diameters), total height of each individual, diameter at the base and each stratum density (tree, bush and regenerate). The data for each stratum included in the forest inventory were calculated by using sampling plots located at the vertices of a $9 \times 9 \mathrm{~km}$ grid. Finally, an overall 111 plots were finally included in the regression analysis.

Individual plots were assessed from data for the plot at the grid vertex, whereas plot groups were assessed both at the grid vertex and in four additional plots within a $1 \times 1 \mathrm{~km}$ square centred at the original plot. The other four plots were in the NW, NE, SW and SE directions of the central plot, 707.1 $\mathrm{m}$ away from the grid vertex

\section{Aboveground phytomass estimation}

The aboveground phytomass for each stratum considered, in addition to Prosopis biomass, was determined. All individuals recorded for all species $(39,425$ individuals $)$ were considered and all the data were converted into unit per hectare values.

Aboveground biomass values were obtained by using equations that estimated the overall biomass in relation to diameter and height (Table 1). The values of the dasometric variables collected in the field inventory compiled between May and July 2000 were incorporated into each equation.
The expression used with Prosopis pallida (aboveground woody dry biomass) was equation 1 (Padrón \& Navarro 2004). The aim of using this equation was that it is specific for the Prosopis pallida in the Piura Province. Although this equation was established only for woody dry biomass, it represents a more accurate estimation of the biomass than using a more general equation, which would accumulate the error of the ecosystem variance in each species biomass. The aboveground phytomass of faique (Acacia huarango,) individuals (aboveground dry biomass) with an arboreal form, was calculated using equation 2 , which was originally derived for a species of the same genus (Acacia magium Willd.) (Kueh \& Lim 1999) (Table 1).

The biomass of the other tree species of the legume family included in the forest inventory (Caesalpinia paipai R. \& P., Cercidium praecox R. \& P. Harms and Parkinsonia aculeata L.) was calculated from the equations for Prosopis pallida (equation 1) as they belonged to the same family and there are no specific equations for these species (Table 1).

Finally, the aboveground phytomass (aboveground dry biomass) for the remaining tree species (viz. Loxopterygium huasango, Bursera graveolens, Capparis angulata and Capparis eucalyptifolia Haught) was calculated by using a revised equation (equation 3 ) for dry forest specific to the studied formation (Mesquite) (Jenkins et al. 2004) (Table 1).

TABLE 1

Equations used to calculate the biomass of each plant species, family or formation Ecuaciones utilizadas para el cálculo de la biomasa para cada especie, familia o formación

\begin{tabular}{|c|c|c|c|c|}
\hline $\begin{array}{l}\text { Individual species or } \\
\text { species groups }\end{array}$ & Equation & $\mathrm{R}^{2}$ & Variables & Source \\
\hline \multirow[t]{2}{*}{ Prosopis pallida H.B.K } & $75.1691+0.08732 *\left[(\mathrm{DAB})^{\wedge} 2\right]^{*} \mathrm{Ht}$ & & & \\
\hline & [Equation 1] & 0.950 & $\mathrm{DAB}(\mathrm{cm}) \mathrm{Ht}(\mathrm{m})$ & Padrón \& Navarro (2004) \\
\hline Acacia huarango & $0.0921^{*}(\mathrm{DBH})^{\wedge} 2.5899[$ Equation 2] & 0.991 & $\mathrm{DBH}(\mathrm{cm})$ & Kueh \& Lim (1999) \\
\hline \multirow[t]{2}{*}{ Mesquite } & $\operatorname{Exp}(-0.7152+1.7029 * \operatorname{Ln}(\mathrm{DBH}))$ & & & \\
\hline & [Equation 3] & 0.938 & $\mathrm{DBH}(\mathrm{cm})$ & Jenkins et al. (2004) \\
\hline Family Asteraceae & $2.361 \_(f c c) 3 / 2$ [Equation 4$]$ & 0.966 & $\mathrm{Fcc}\left(\mathrm{m}^{2}\right)$ & Schenk et al. (2003) \\
\hline Bush stratum & $-0.095+36.26 * \mathrm{fcc}$ [Equation 5] & 0.921 & $\operatorname{Fcc}(\%)$ & Mattiske (1975) \\
\hline
\end{tabular}


Charamusco (Encelia canescens) was the bush species (aboveground dry biomass) with the largest number of individuals recorded. Because no allometric equations for calculating its biomass at the species or genus level were available, an equation (equation 4) for another genus (Acamtopappus) (aboveground dry biomass) of the same family (Asteraceae) was employed (Schenk et al. 2003) (Table 2). Because faique (Acacia huarango) was the second most important species and no specific equations for calculating its biomass existed, the equation 5 applicable to bush formations (aboveground dry biomass) including the genus Acacia (as a bush) was used and extended to the other individuals in the bush stratum (Mattiske 1975) (Table 1).

Aboveground biomass of regenerate biomass was calculated using the same equation as for the bush stratum (equation 5) as the weight of this variable was negligible with respect to the previous ones and finding a regression equation for each species would have been far beyond the scope of this work. This equation was preferred to the one for the Asteraceae family because the faique regenerate was more abundant than the charamusco regenerate $(3,687$ versus 665 individuals) (Table 1).

The overall biomass was calculated by adding the regenerate, the bush and the tree biomass weight for each plot.

\section{Forest stratification}

The vegetation types were separated into two classes according to the presence of Prosopis pallida as the main species in the tree strata or the existence of a mixed forest. After that, the forest was divided according to the percentage of ground cover: very sparse $(10-50 \%$ ground cover) or sparse (50-100\% ground cover). Zones with less than $10 \%$ of ground cover were considered as non-forest or non-cover. The nomenclature used was VSDF for "very sparse dry forest" and SDF for "sparse dry forest". Also, a distinction was made between areas of bushes (Bush) and non-cover (NC). Finally, dense forests were split into two categories (viz. dense and very dense) owing to the great variability of their variances in aboveground biomass. In this way, the plots with extremely high biomass values, most of which were due to the individual characteristics of the plots rather than to the type of dry forest studied, were separated from the rest. The nomenclature used was VDDF for "very dense dry forest" and DDF for "dense dry forest".

\section{Pre-processing of images}

Three images acquired by the Landsat 7 ETM+ scenes captured in May 2000 (Path 11, Row 63 and Path 10 Row 64) and one in January 2000 (Path 10, Row 64) were used in this work (Fig. 1). The software used to process the satellite images was ERDAS 8.4 imagine.

A mosaic was constructed with these three scenes spanning the whole studied forest. The images were georeferenced with 30 suitably distributed points that were acquired by GPS. Corrections were performed by using a thirdorder polynomial with the nearest-neighbour method. The total RMSE error was 0.4 pixel $(12 \mathrm{~m})$. Image data were radiometrically corrected using standard methods for

TABLE 2

Formulae used to calculate the different vegetation indices

Fórmulas para el cálculo de los índices de vegetación

\begin{tabular}{lcc}
\hline Index & Formula & Source \\
\hline NDVI & $(\mathrm{TM} 4-\mathrm{TM} 3) /(\mathrm{TM} 4+\mathrm{TM} 3)[$ Equation 6] & Huete \& Jackson (1987) \\
NDMI & $(\mathrm{TM} 5-\mathrm{TM} 4) /(\mathrm{TM} 5+\mathrm{TM} 4)[$ Equation 7] & Cibula et al. (1992) \\
N37I & $(\mathrm{TM} 3-\mathrm{TM} 7) /(\mathrm{TM} 3+\mathrm{TM} 7)[$ Equation 8] & Boyd et al. (1996) \\
SAVI & $(1+\mathrm{L})+(\mathrm{TM} 4-\mathrm{TM} 3) /(\mathrm{TM} 4+\mathrm{TM} 3+\mathrm{L}) \mathrm{L}=1[$ Equation 9] & Huete (1988) \\
MSAVI & {$\left[(2 * \mathrm{TM} 4+1)+\left[(2 * \mathrm{TM} 4+1)^{\wedge} 2-8 *(\mathrm{TM} 4-\mathrm{TM} 3)\right]^{\wedge} 1 / 2\right] / \mathrm{TM} 3[$ Equation 10] } & Qi et al. (1994) \\
EVI & $\mathrm{G}^{*}(\mathrm{TM} 4-\mathrm{TM} 3) /(\mathrm{TM} 4+\mathrm{C} 1 * \mathrm{TM} 3-\mathrm{C} 2 * \mathrm{TM} 1+1) \mathrm{L}=1, \mathrm{C} 1=6, \mathrm{C} 2=7.5, \mathrm{G}=2.5$ & Huete et al. (2002) \\
& {$[$ Equation 11] } &
\end{tabular}


conversion of digital data into spectral radiance values based on the formula of Markham \& Barker (1986) and subsequently transformed into reflectance values using the earth-sun distance, solar irradiance and zenith angle for the day and time each image was obtained. Radiometric corrections were based on the coefficients of the bands 1-5 and 7 in the head files of the Landsat images (http:// ltpwww.gsfc.nasa.gov/IAS/handbook/ handbook_htmls/chapter11/chapter11.html).

The use of absolute atmospheric corrections in order to handle actual reflectance values was considered. Some authors (Song et al. 2001) believe that the methods available for calculating such values may not be the most effective ones for analyzing forest changes; however, the use of images acquired at different moments of the year or in different years entailed considering atmospheric effects on reflectance. In this study, a relative atmospheric correction based on the information contained in the three images using a pseudo-invariant points treatment was used based on 31 samples (e.g., roads) that were selected from a visual inspection of the study area (Schott et al. 1988, Hall \& Hay 2003). This method does not decrease the magnitude of change between scenes (Yang \& Lo 2000).

\section{Indices used}

A number of general vegetation indices including the normalized difference vegetation index (NDVI) (Huete \& Jackson 1987), normalized difference moisture index (NDMI) (Cibula et al. 1992) and other ratios integrating the Landsat-TM sensor bands 3 and 7 (Boyd et al. 1996) have been reported. Additional indices have been developed in order to consider atmospheric effects in addition to discriminating vegetation. One such index is the enhanced vegetation index (EVI) developed by NASA (Huete et al. 2002) (Table 2).

One of the main difficulties faced in studying low-density forests by using remote sensing techniques is the need to separate soil and vegetation effects (Huete 1988). As the ground cover in these ecosystems is often less than $100 \%$, pixels contain mixed information for both components. This shortcoming has been addressed by using indices such as the soil adjusted vegetation index (SAVI) (Huete
1988). The SAVI uses a calibration curve for soil values to resolve them from the reflectance values due to the vegetation. This index was subsequently refined to the modified soil adjusted vegetation index (MSAVI), which requires no calibration curve and varies with the plant cover (Qi et al. 1994).

The indices used in this study and their formulae are listed in Table 2. The normalized difference vegetation index (NDVI) (ArroyoMora et al. 2003, Hurcon \& Harrison 1998) is the one most widely used in remote sensing applications on account of its ability to represent the relative state of vegetation.

The normalized difference moisture index (NDMI) is the wavelength difference between bands TM4 and TM5 (middle infrared), band TM5 representing plant water content (Cibula et al. 1992, Hunt et al. 1987). An index recommended for studying tropical forests and, more specifically, for estimating regeneration (Boyd et al. 1996), is N37I, which uses a ratio between bands TM5 and TM7 to determine vegetation-related parameters. The soil adjusted vegetation index (SAVI) (Huete 1988) was designed to reduce the influence of the reflectance of soil under a plant cover in studying open covers. It uses a reference curve with a coefficient $L$ to separate the effects of soil reflectance and vegetation reflectance. The modified soil adjusted vegetation index (MSAVI) is an improved variant of the SAVI, which uses a variable coefficient depending on changes in the red and infrared region (Qi et al. 1994). The enhanced vegetation index (EVI) optimizes the sensitivity of the vegetation signal in areas of abundant biomass and is used to separate the vegetation signal from the background signal in order to reduce atmospheric effects (Huete et al. 2002).

\section{Statistical analysis}

The data obtained from the plots were subjected to different types of statistical analysis using the software Statgraphics Plus 5.1. First, an analysis of variance (ANOVA) was used to compare the biomass means for each vegetation type (no cover/bush/very sparse dry forest/sparse dry forest). Significant differences between means were identified using Fisher's least significant difference (LSD) test (Devore 2004). 
Then, a Pearson correlation matrix was constructed in order to identify the index providing the best correlation with the aboveground phytomass data. Pixel values for the vegetation indices were extracted by using a matrix of $3 \times 3$ pixels georeferenced to each point acquired with the GPS and subsequently related to the indices. The other procedures involved regressions of aboveground biomass for each extracted index, in order to identify the best correlations between vegetation indices and aboveground biomass, and a correlation matrix was developed. All the statistical results were subjected to the lack-of-fit test to check whether the model concerned accurately predicted variations in the data.

\section{RESULTS}

\section{Forest stratification}

The forest stratification for Prosopis pallida ecosystem data is shown in Table 3. The regeneration of Prosopis was greater in the Prosopis pallida forest than in the mixed forest. In general, there was a positive relationship between the Prosopis pallida ground cover and its regeneration. As can be seen, most of the plots had Prosopis pallida as their main species and mixed forest plots were scant. Based on the foregoing, the results were reclassified by ignoring the difference between mixed and Prosopis pallida forests and grouping them in terms of ground cover alone.

\section{Quantifying biomass from the satellite images}

Table 4 shows the aboveground biomass values obtained for each vegetation stratum in the forest inventory. The overall biomass varied from 0 to $9.9 \mathrm{Mg} \mathrm{ha}^{-1}$. EVI and NDVI were the best estimators for biomass (Table 5) in both mosaics. However, EVI showed better correlations and this index was finally selected to evaluate the biomass in the Piura Province. The regression equations relating the field values of overall biomass to EVI is shown in Table 6, with a parabola-like curve of $\mathrm{R}^{2}=0.85$ for overall biomass and $\mathrm{R}^{2}=0.72$ for tree biomass.

The means of biomass for each prediction range was established using the Equations 12, which was the one providing the optimal separation between forest types. Based on ANOVA results, Table 7 shows the overall biomass values obtained as a function of EVI from the January-May 2000 mosaic.

TABLE 3

Mean ground cover $( \pm$ SE) for each vegetation stratum and the species Prosopis pallida in each type of forest (in terms of tree ground cover)

Cobertura media $( \pm$ EE) para cada estrato de vegetación y para Prosopis pallida en cada tipo forestal establecido

\begin{tabular}{|c|c|c|c|c|c|c|c|c|}
\hline \multirow[t]{2}{*}{ Forest type } & \multirow[t]{2}{*}{$\mathrm{n}$} & \multicolumn{7}{|c|}{ Ground cover $\left(\mathrm{m}^{2} \mathrm{ha}^{-1}\right)$} \\
\hline & & $\begin{array}{c}\text { Overall } \\
\text { tree* }\end{array}$ & Tree & Bush & Regeneration & $\begin{array}{c}\text { Prosopis } \\
\text { pallida }\end{array}$ & $\begin{array}{l}\text { Prosopis } \\
\text { regeneration }\end{array}$ & $\begin{array}{l}\text { Overall } \\
\text { cover }\end{array}$ \\
\hline Prosopis pallida VSDF & 55 & $4,768(135)$ & $2,573(112)$ & $6,247(245)$ & $4,235(143)$ & $2,195(108)$ & $3,563(169)$ & $18,813(777)$ \\
\hline Prosopis pallida SDF & 18 & $13,346(344)$ & $7,018(267)$ & $9,506(421)$ & $2,244(134)$ & $6,238(219)$ & $1,633(97)$ & $26,729(1138)$ \\
\hline Prosopis pallida DDF & 9 & $33,442(780)$ & $17,900(611)$ & $12,722(532)$ & $1,219(87)$ & $15,542(567)$ & $456(19)$ & 47,839 (1816) \\
\hline Mixed VSDF & 6 & $2,624(93)$ & $2,260(102)$ & $4,455(201)$ & $250(12)$ & $364(21)$ & $30(3)$ & $7,359(339)$ \\
\hline Mixed SDF & 2 & $12,941(456)$ & $9,321(287)$ & $7,933(321)$ & $934(43)$ & 3,620 (129) & 0 & $21,808(780)$ \\
\hline Mixed DDF & 2 & $17,143(567)$ & $12,648(502)$ & 4,131 (187) & $3,859(123)$ & 4,495 (176) & $191(23)$ & $25,324(1011)$ \\
\hline Bush & 19 & $611(23)$ & $351(17)$ & $2,336(125)$ & $521(21)$ & $260(18)$ & $248(19)$ & $3,716(200)$ \\
\hline
\end{tabular}

*Overall tree cover $=$ tree cover + Prosopis pallida cover;

VSDF: very sparse dry forest; SDF: sparse dry forest; DDF: dense dry forest 
TABLE 4

Mean biomass $( \pm \mathrm{SE})$ in $\mathrm{Mg} \mathrm{ha}^{-1}$ for each vegetation type. Different letters indicate significant differences between treatments at $\mathrm{P}$ $\leq 0.05$ (ANOVA, LSD test)

Valor medio de biomasa ( $\pm \mathrm{EE})$ en $\mathrm{Mg} \mathrm{ha}^{-1}$ para cada tipo de vegetación. Letras diferentes indican diferencias significativas a $\mathrm{P} \leq 0,05$ (ANOVA, prueba LSD)

\begin{tabular}{lc}
\hline Forest type & Aboveground biomass $\left(\mathrm{Mg} \mathrm{ha}^{-1}\right)$ \\
\hline No cover & $0 \mathrm{a}$ \\
Bush & $1.154(0.096) \mathrm{a}$ \\
Very sparse dry forest & $4.451(0.237) \mathrm{b}$ \\
Sparse dry forest & $9.984(0.879) \mathrm{c}$ \\
\hline
\end{tabular}

\section{DISCUSSION}

The data obtained from Prosopis pallida forests in Piura were used in conjunction with allometric relations to calculate the biomass for the different dry forest vegetation strata present in the study area. The overall biomass values for the Prosopis pallida H. B. K. ecosystem in the Piura Province in the year 2000 as estimated from the forest inventory ranged from 0 to 9.98 $\mathrm{Mg} \mathrm{ha}{ }^{-1}$. These values are consistent with the previously reported mean estimates for desertic or subdesertic forests $\left(7 \mathrm{Mg} \mathrm{ha}^{-1}\right)$ in various ecosystems worldwide (Terradas 2001).

The forest inventory for the year 2000 was also used to estimate the ground cover for each vegetation stratum (tree, bush and regenerate) and the different forest types established in terms of the tree ground cover. As can be seen, the forest types with the lowest tree ground covers were those exhibiting the highest proportions of regenerate. Also, the regenerate values for Prosopis pallida were higher for monospecific dry forests than for mixed forests. This is an important criterion in choosing a specific classification to estimate natural regeneration and deforestation in Prosopis pallida ecosystems as the tree stratum is related to the regenerate stratum.

TABLE 5

Pearson correlations matrix between aboveground biomass (lines) and vegetation indices (columns). Pearson's correlation index and level of significance

Matriz de correlación de Pearson entre la biomasa aérea y los índices de vegetación estudiados

\begin{tabular}{ccccccccc}
\hline & & $\begin{array}{c}\text { Aboveground } \\
\text { biomass }\end{array}$ & EVI & MSAVI & N37I & NDMI & NDVI & SAVI \\
\hline Aboveground biomass & $\mathrm{P}$ & 1 & 0.8120 & 0.5407 & -0.3041 & -0.2329 & 0.7954 & 0.7730 \\
& Significance & & $* *$ & $*$ & $\mathrm{~ns}$ & $\mathrm{~ns}$ & $* *$ & $*$ \\
\hline
\end{tabular}

ns: not significant at $\mathrm{P}=0.05 ; *$ Significant at $\mathrm{P}=0.01-0.05$ level; ** Significant at $\mathrm{P}=0.001-0.01$

TABLE 6

Single regression equations with the highest correlation values between aboveground biomass versus EVI

Ecuaciones de regresión simple con los mayores valores de correlación entre la biomasa aérea y el índice EVI

\begin{tabular}{lccccccccc}
\hline Variable Y & Variable Y $\left(\mathrm{kg} \mathrm{ha}^{-1}\right)$ & $\mathrm{n}$ & $\mathrm{R}$ & $\mathrm{R}^{2}$ & $\mathrm{P}$ & $\mathrm{SE}$ & $\mathrm{a}$ & $\mathrm{b}$ & Equation type \\
\hline EVI & Overall biomass & 111 & 0.85 & 0.72 & $<0.001$ & 20.95 & -1615.60 & 9.74613 & $\begin{array}{l}\mathrm{y}=\left(\mathrm{a}+\mathrm{b}^{*} \mathrm{x}\right)^{2} \\
{[\text { Equation 12] }}\end{array}$ \\
& & & & & & & & & \\
EVI & Tree biomass & 111 & 0.72 & 0.52 & $<0.001$ & 23.92 & -1187.65 & 7.16453 & $\begin{array}{l}\mathrm{y}=\left(\mathrm{a}+\mathrm{b}^{* x}\right)^{2} \\
{[\text { Equation 13] }}\end{array}$ \\
\hline
\end{tabular}

Coefficients of correlation $\mathrm{R}$ and $\mathrm{R}^{2}$, number of plots (n), significance level (P), standard error (SE), equation coefficients and type of equation used 
TABLE 7

Aboveground biomass, EVI, and $95 \%$ confidence limits of biomass estimation for each forest type Valor medio de la biomasa, el índice EVI y 95 \% límites de confianza en la estimación de biomasa para cada tipo forestal

\begin{tabular}{|c|c|c|c|c|c|c|}
\hline & \multirow[t]{2}{*}{ Biomass $\left(\mathrm{Mg} \mathrm{ha}^{-1}\right)$} & \multirow[t]{2}{*}{ EVI } & \multicolumn{2}{|c|}{ Prediction limits (95\%) } & \multicolumn{2}{|c|}{ Confidence limits $(95 \%)$} \\
\hline & & & $\begin{array}{l}\text { Minimum } \\
\left(\mathrm{Mg} \mathrm{ha}^{-1}\right)\end{array}$ & $\frac{\text { Maximum }}{\left(\mathrm{Mg} \mathrm{ha}^{-1}\right)}$ & $\begin{array}{l}\text { Minimum } \\
\left(\mathrm{Mg} \mathrm{ha}^{-1}\right)\end{array}$ & $\begin{array}{c}\text { Maximum } \\
\left(\mathrm{Mg} \mathrm{ha}^{-1}\right)\end{array}$ \\
\hline No cover & 0 & $<-0.020$ & 0 & 1.79 & 0 & 0.07 \\
\hline Bush & 1.00 & 0.0507 & 0 & 5.40 & 0.67 & 1.38 \\
\hline VSDF & 4.50 & 0.1089 & 6.43 & 11.83 & 3.98 & 5.04 \\
\hline SDF & 10.00 & 0.1634 & 3.37 & 20.13 & 8.89 & 11.17 \\
\hline
\end{tabular}

VSDF: very sparse dry forest; SDF: sparse dry forest

A new classification of forests based on a single variable, the ground cover (for trees, bushes and regenerate), was proposed whether it belonged to forests having Prosopis pallida as their main species or to mixed forests. These classifications have the advantage that forest types can be easily separated for referencing to satellite images. This is a result of the difficulty of distinguishing individual dry forest species among them. Remote sensing studies on open masses usually rely on a vegetation estimator rather than on a species-based criterion, i.e. they seek to discriminate vegetation abundance (Huete 1988) more than the individual species constituting the vegetation.

Ground cover is a biophysical parameter that can easily be measured in a traditional forest inventory and it is also sensitive to remote sensing sensors (Cohen et al. 2003). Therefore, dry forest can be inventoried and typified in order to develop a biomass study with remote sensing techniques. These results have an immediate implication in choosing the specific classification to be used in the present study of dry forests. Thus, the use of a classification relying on a combined (tree and bush) ground cover should be discarded as it does not allow the very sparse and sparse forest types to be distinguished.

As regards biomass calculations from satellite images, two equations for estimating overall biomass and tree biomass with the EVI index were developed. This had two major implications: (i) the tree stratum was the principal stratum as regards biomass; and (ii) biomass values were positively correlated with the vegetation index and EVI $\left(\mathrm{R}^{2}=0.85\right)$, which can herewith be used as effective estimators for the biomass of the Prosopis pallida ecosystem. The results of the variance analysis reveal that forest typing models including the variable tree biomass are effective for studying Prosopis pallida dry forests to establish an inventory procedure which allows the acquisition of field data for remote sensing studies. Of the vegetation indices used to estimate biomass, those involving some atmospheric correction (EVI in our case) are desirable with a view to comparing images acquired on different dates.

Landsat images have been used for a variety of purposes in biomass studies. Thus, Cook et al. (1989) examined the usefulness of the Landsat TM satellite and biogeographic data to estimate forest productivity as the mean annual increase in available volume in local inventories. Their regressions were highly significant, but they do not report $\mathrm{R}^{2}$ data. However, they failed to account for most of the variance in the data $\left(\mathrm{R}^{2}\right.$ ranged from 0.27 to 0.42). The models of Ung et al. (2000) accounted for merely $11-30 \%$ of the variability in their data. Houghton (2003) performed biomass calculations based on canonical correlation analysis (CCA), Cohen et al. 2003 did as well, using LAI and ground cover values to obtain $\mathrm{R}^{2}=0.52$. However, Lee \& Nakane (1996) obtained an $\mathrm{R}^{2}$ of 0.73 by using a small sample $(\mathrm{n}=9)$ of field values to estimate biomass. Meyer et al. (1996), using a sample of identical size $(n=9)$ in conjunction with vegetation indices and SPOT images, obtained 
an $\mathrm{R}^{2}$ of 0.57 by applying a non-linear equation. Finally, Lu et al. (2002) obtained $\mathrm{R}^{2}$ values of between 0.627 and 0.88 for wet tropical forests. Compared to these regression studies, the result of $\mathrm{R}^{2}=0.85$ obtained for the Piura Province $(\mathrm{n}=111)$ improves on previously reported values and is reasonably acceptable with a view to calculating biomass for the Prosopis pallida ecosystem.

It should be noted that the NDVI values were positively correlated, which is consistent with the results of previous regression analyses (Arroyo-Mora et al. 2003; Cohen et al. 2003). By contrast, the soil indices exhibited relatively low correlations. The EVI exhibited the highest correlation obtained with this type of regression for aboveground biomass, the most plausible explanation for this being that the inclusion of a correction factor with the values for band 1 reduces atmospheric influences and optimizes the sensitivity towards biomass-rich zones (Huete et al. 2002). The use of images acquired in January and May in this work allowed the influence of the atmospheric effect to be reduced by the index as vegetation changes were insubstantial, the 1999-2000 period being one of scant precipitation ("El Niño" did not occur) and slight seasonal changes.

Equation overall biomass $=(-1615.60+$ $\left.9.74613^{*} \mathrm{EVI}\right)^{2}$ was recommended for estimating biomass for the Piura Province in the year 2000 as it was the one providing the best $r^{2}$ values and the best balance between points with scant biomass and points with abundant biomass.

\section{LITERATURE CITED}

ARROYO-MORA P, A SÁNCHEZ-AZOFEIFA, B RIVARD \& C CALVO (2003) Integrating very high and high resolution imagery for detecting secondary growth in a Neotropical dry forest ecosystem: a vegetation indices approach. Anais XI SBSR: 26552662.

BONHAM C (1989) Measurements for terrestrial vegetation. John Wiley and Sons, New York, New York, USA. 338 pp.

BOYD D, G FOODT, P CURRANT \& R LUCAS (1996) An assessment of radiance in Landsat TM middle and thermal infrared wavebands for the detection of tropical forest regeneration. International Journal of Remote Sensing 17: 249-262.

CHUVIECO E (1995) Fundamentos de la teledetección espacial. Ediciones Rialp, S.A, Madrid, España. 453 $\mathrm{pp}$.

CIBULA W, E ZETKA \& D RICKMAN (1992) Response of thematic mapper bands to plant water stress. International Journal of Remote Sensing 13: 1869 1880 .

COHEN W, T MAIERSPERGER \& S GOWER (2003) An improved strategy for regression of biophysical variables and Landsat ETM+ data. Remote Sensing of Environment 84: 561-571.

COLLIN H, C HUANG, L YANG \& B WYLIE B (2000) Development of a CIRCA 2000 landcover database for the United States (electronic version). [http:// landcover.usgs.gov/pdf/asprs_final.pdf]

COOK E A, L IVERSON \& R GRAHAM (1989) Estimating forest productivity with thematic mapper and biogeographical data. Remote Sensing of Environment 28: 131-141.

DEVORE J (2004) Probability and statistics for engineers and scientists. Third edition. Thompson Brooks/ Cole, Belmont, Tennessee, USA. $750 \mathrm{pp}$

GUERRA F, H PUIG \& R CHAUME (1998) The forestsavannah from multi-date Landsat-TM data in Sierra Parima, Venezuela. Photogrammetric Engineering and Remote Sensing 19: 2061-2075.

HALL O \& G HAY (2003) Multiscale object-specific approach to digital change detection. International Journal of Applied Earth Observation and Geoinformation 4: 311-327.

HÄME T, A SALLI, K ANDERSSON \& A LOHI (1997) A new methodology for the estimation of biomass of conifer dominated boreal forest using NOAA AVHRR data. International Journal of Remote Sensing 18: 3211-3243.

HOUGHTON R A (2003) Revised estimates of the annual net flux of carbon to the atmosphere from changes in land use and land management 1850-2000. Tellus 55: $378-390$.

HUETE A (1988) A soil-adjusted vegetation index (SAVI). Remote Sensing of Environment 25: 295 309.

HUETE A \& R JACKSON (1987) Suitability of spectral indices for evaluating vegetation characteristics on arid rangelands. Remote Sensing of Environment 23: 213-232.

HUETE A, K DIDAN, T MIURA, E RODRIGUEZ, X GAO \& L FERREIRA (2002) Overview of the radiometric and biophysical performance of the MODIS vegetation indices. Remote Sensing of Environment 83: 195-213.

HURCON S \& A HARRISON (1998) The NDVI and spectral decomposition for semi-arid vegetation abundance estimation. International Journal of Remote Sensing 19: 3109-3125.

INRENA (1998) Memoria descriptiva. Mapa forestal de bosques secos del Perú. Ministerio de Agricultura, Dirección General de Estudios y Proyectos de Recursos Naturales, Lima, Perú. 86 pp.

JENKINS J, D CHOJNAKY, L HEATH \& R BIRDSEY (2004) Comprehensive database of diameter-based biomass regressions for North American tree species. United States Department of Agriculture, Forest Service, Delaware, USA. 48 pp.

KUEH R \& M LIM (1999) Forest biomass estimation in Air Hitam Forest Reserve, May 2002 (electronic version). [http://www.geocities.com/ EnchantedForest/Palace/ 1170/ biomass.html].

LEE N J \& K NAKANE (1997) Forest vegetation classification and biomass estimation based on Landsat TM data in a mountainous region of west Japan. Forestry Sciences 50: 159-171.

LU D, P MAUSEL, E BRONDÍZIO \& E MORAN (2002) Relationships between forest stand parameters and 
Landsat TM spectral responses in the Brazilian Amazon basin. Forest Ecology and Management 198: 149-167.

MARKHAM B \& J BARKER (1986) Landsat MSS and TM post-calibration dynamic ranges, exoatmospheric reflectances and at satellite temperatures. EOSAT: Landsat Technical Notes 1: 3-5.

MATTISKE E (1975) Effects of man on the vegetation in the national parks of South Australia. Ph.D. thesis, Department of Botany, University of Adelaide, Adelaide, Australia. 96 pp.

MEYER P, K STAENZ \& K ITTEN (1996) Semiautomated procedures for tree species identification in high spatial resolution data from digitized colour infrared-aerial photography. ISPRS Journal of Photogrammetry and Remote Sensing 51: 5-16.

PADRÓN E \& R NAVARRO-CERRILLO (2004) Estimation of above-ground biomass in naturally occurring populations of Prosopis pallida (H. \& B. ex. Willd.) H.B.K. in the north of Peru. Journal of Arid Environments 56: 283-292.

PUA M \& H SAITO (2003) Estimation of biomass of a mountainous tropical forest using Landsat TM data. Canadian Journal of Remote Sensing 29: 429-440.

QI J, A CHEHBOUNI, \& A HUETE (1994) A modified soil adjusted vegetation index. Remote Sensing of Environment 48: 119-126.

REICH P, D TURNER \& P BOLSTAD (1999) An approach to spatially distributed modelling of net primary production (NPP) at the landscape scale and its application in validation of EOS NPP products. Remote Sensing of Environment 70: 69-81.

ROPER J \& R ROBERTS (1999) Deforestation: le declin des forêts tropicales. Hull (Quebec), Agence Canadienne de Développement International, Quebec, Canada. 54 pp.

Associate Editor: Julio Gutiérrez

Received May 8, 2006; accepted September 11, 2006
SCHENK H, C HOLZAPFEL, J HAMILTON \& B MAHALL (2003) Spatial ecology of a small desert shrub on adjacent geological substrates. Journal of Ecology 91: 383-395.

SCHOTT J, C SALVAGGIO \& W VOLCHOK (1988) Radiometric scene normalization using pseudoinvariant features. Remote Sensing of Environment 26: $1-16$.

SHU G (2003) Detection and analysis of land cover dynamics in moist tropical rainforest of south Cameroon (electronic version). [http://www.itc.nl/ library/ Papers_2003/ msc/ nrm/shu.pdf].

SONG C, C WOODCOCK, K SETO, M LENNEY \& S MACOMBER (2001) Classification and change detection using Landsat TM data: when and how to correct atmospheric effects? Remote Sensing of Environment 75: 230-244

STENINGER M (2000) Satellite estimation of tropical forest above-ground biomass: data from Brazil and Bolivia. International Journal of Remote Sensing 21: $1139-1157$.

TERRADAS J (2001) Ecología de la vegetación. De la ecofisiología de las plantas a la dinámica de comunidades y paisajes. Editorial Omega, Barcelona, España. 703 pp.

UNG A, T RAUCHIN, L WALD, C WEBER, T HIRSCH, G PERRON \& J KLEINPETER (2000) Air pollution mapping; a new approach based on remote sensing and geographical database. Application to the city of Strasbourg. Photo-interpretation 3-4: 5363.

YANG X \& C LO (2000) Relative radiometric normalization performance for change detection form multidate satellite images. Photogrammetric Engineering and Remote Sensing 66: 967-980. 
